\title{
Understanding the impact of COVID-19 in the spiritual life of the Church community
}

\author{
Thandiwe Nonkululeko Ngema \\ Faculty of Education, Department of Arts and Language Education \\ University of Zululand, South Africa \\ ORCiD- https://orcid.org/0000-0002-5915-5619 \\ Email-NgemaT@unizulu.ac.za \\ Zanele Gladness Buthelezi \\ Faculty of Arts, Department of African Languages and Culture \\ University of Zululand, South Africa \\ ORCiD- https://orcid.org/0000-0002-4330-8094 \\ Dumisani Wilfred Mncube \\ Faculty of Education, Department of Social Sciences in Education \\ University of Zululand, South Africa \\ ORCiD- https://orcid.org/0000-0001-5566-22885
}

\begin{abstract}
The COVID-19 pandemic has affected the world in extra-ordinarily negative ways. Its impact has been felt in government circles, families, communities and churches globally. Spiritual leadership together with church members or congregants has also suffered a great deal. The pandemic has successfully disorganized societies and religious communities. Its spiritual impact has been felt by church leaders and congregants alike. This study investigated the spiritual impact COVID-19 has imposed on church leadership and congregants. It also explores how some church leaders performed their pastoral ministry under COVID-19 conditions. To achieve the set objective, a qualitative methodology and interpretive paradigm were adopted. In-depth individual interviews with church leaders and church members from Christian churches were used to inform the study. Ten churches that operate within the Esikhaleni fraternity, in KwaZulu-Natal, South Africa, under uMhlathuze municipality participated in the data generation process.

The study comprised a sample size of four church leaders and eight church members from ten churches. A total number of 12 twelve heterogeneous individual participants were purposively selected. Findings revealed that the prevalence of COVID-19 led to lockdown restrictions and as such, church house closure impacted the church family positively as well as negatively. The study recommends that church leaders be proactive in accommodating change and equip their congregants accordingly. Secondly, churches should adapt to multi-staff ministry where lay people are actively involved in educating congregants about pandemics in general and how to cope spiritually. Third, it is argued church leadership should embrace virtual and internet ministry so as to continue to offer spiritual support to congregants.
\end{abstract}

Doi: https://doi.org/10.46222/pharosjot.102.27

Keywords: COVID-19 pandemic, spiritual impact, church leadership, congregants, church community. 
Pharos Journal of Theology ISSN 2414-3324 online Volume 102 - Special Ed 2 (2021)

Copyright: @2021 Open Access/Author/s - Online @ http//: www.pharosjot.com

\section{Introduction}

Pandemics can cause sudden, widespread morbidity and mortality associated with emotional, psychological, social, political, economic and spiritual disruptions. The world has endured several notable pandemics in the past, including the Black Death, Spanish flu, and human immunodeficiency virus/acquired immune deficiency syndrome (HIV/AIDS) (Madhav, Oppenheim, Gallivan, Mulembakani, Rubin \& Wolfe, 2017). Likewise, the novel Coronavirus (COVID 19) has shaken the whole world especially the church. Murff (2020) announced that the world is entering into an unprecedented new era for the Church. In this instance, it has a profound spiritual impact on Christians. Madhav et al (2017), posit that pandemics are large-scale outbreaks of infectious disease that can greatly increase morbidity and mortality over a wide geographic area and cause significant economic, social, and political disruption. Additionally, Porta (2014) illuminates that pandemics occur over a wide area, cross international boundaries, and usually affect a large number of people. Correspondingly, the World Health Organisation (2010) concurs with various researchers and adds that a pandemic is defined by a new virus that emerges and spreads around the world, and most people do not have immunity to it. The observable similarities among the pandemics have been enormous deaths among the rich and poor, urban and rural, young and old, among all colours and races (Moon et al., 2015; Madhav et al., 2017; Marshall, 2020; WHO, 2016b; Pathmanathan et al., 2014).

The COVID-19 era has imposed a serious spiritual impact on everyone. For example, the era of COVID-19 has seen the inability of properly taking care of the ill by the loved ones, the idea of experiencing an isolated death in hospitals where relatives were denied entry for visits, the sudden overcrowding in hospitals, the lack of space to accommodate the dead in mortuaries, the shortage of coffins and, the shortage of men to dig graves for burials (Murff, 2020; Merrit, 2020; Osei, 2020; Lonas, 2020). Doom and gloom covered the whole world. Pandemics have the following characteristics: they quickly overload the health system, they fill people with the anxiety of wondering what the future holds, losing jobs and many other worrying thoughts, and they also fill people with the fear of everything. People become paranoid. They sometimes experience a sense of helplessness (Rubison et al., 2013). Additionally, Falcone and Detty (2015), warn that fearful people may seek unnecessary care, thus burdening the health care system. Undoubtedly, the mentioned characteristics have a negative bearing on spirituality.

The speed with which the virus spread forced governments of the world to take precautionary measures to close the schools, churches, workplaces, theatres, sporting activities and forbade any form of public gathering (Bettis, 2020; Calo et al. (2020); \& Marshall, 2020). According to Grimke (2019), many people referred to closures and forbidding of gatherings as the extraordinary exercise of power by Commissioners although such closures were warranted. To some people, restricting the numbers of people who could attend funerals to pay tribute to loved ones was regarded as being somewhat 'cruel'. This has left indelible marks in the spiritual lives of people from all nations (Falcone \& Detty, 2015 \& Merrit, 2020). The magnitude of the COVID-19 impact has been felt physically, emotionally, financially and spiritually (Grimke, 2019; Lonas, 2020; Bettis, 2020). In this instance, Marshall (2020) posits that the COVID-19 crisis involves both 'sprints and marathons' and familiar yet unprecedented challenges that will have far-reaching repercussions for global affairs. Likewise, the spiritual scars which may result are also inevitable.

Different authors have given accounts of the impact of pandemics other than COVID-19 have had on different societies. People viewed the pandemic from different angles. From the religious perspective, some saw it as God's conspicuous and vigorous way of pronouncing his presence and a way of beating sense into the heads of those that deemed themselves superior to others (Grimke, 2019). Marshall (2020) posits that the spread and treatment of various pandemics have 
been exacerbated by inequalities in health care, lags in appreciating the role of religious leaders in shaping public attitudes and weak mechanisms to engage different communities. This article is more concerned with the spiritual impact of COVID-19 on individuals and churches. It, therefore, is unavoidable to define spirituality. Grimke (2019), Tabei et al. (2016) and Madhav et al (2017) define spirituality as an aspect of human life that encompasses a series of meanings that underline aspiration, compatibility, vision, beliefs, and the meaningfulness of conditions. To this effect, it is an inextricable element of human life and an important factor that enables humans to overcome numerous challenges.

The importance of spirituality in this discussion is that religious beliefs and spirituality are deemed beneficial to the maintenance of physical and psychological health, a reality which, once more, revives the idea of the integration of the body and the psyche (Tabei et al., 2016). Hence the topic: the spiritual impact of COVID-19. Contrary to what Jamir (2020) claimed that pandemics disproportionately affect people living in the world's poorest places, COVID-19 neither chose the lowly and hungry nor the rich and wealthy but blanketed the whole world at once. It is important though, to touch base with the historical account of pandemics and how spiritual leaders handled situations

\section{Historical contexts of pandemics and the spiritual impact}

There have been many historical accounts of pandemics that have attacked different countries within various timelines. The earliest is the Plague of Cyprian between 249 to $262 \mathrm{CE}$, where, in Rome, a lethal pandemic ended up killing 5,000 people a day. This inevitably imposed spiritual heaviness among church leaders as well as congregants. A heroic stance was taken by Cyprian the Bishop of Alexandria, who maintained that Christian leaders while being heedless of danger, took charge of the ill, attending to their every need and ministering to them in Christ, and with them departed this life serenely happy. Christians did get infected but they stood firmly on the belief that plagues intensify the natural course of life, sense of mortality and frailty and they also intensify opportunities to display countercultural, counter conditional love (Stark, 1996; Berding, 2020; Witvliet, 2020). Consequently, the Cyprian Bishop of Alexandria avers that through such love, Christianity won the admiration and a greater following. Based on the courage church leaders showed in caring for the sick, the Bishop of Carthage, understood plagues to be a way of searching integrity among Christians. Moreover, he believed that plagues discover either the way of the flesh (self-preservation) or the way of the Spirit (self-giving sacrifice) in Christians. History tells us that Christians remained stronger, resilient and more of them survived. Their resilience is attributed to their possession of robust hope in the face of death (Contagion infectious diseases today, 2017; De Witte, 2014; Falcone \& Detty, 2015; Parpia et al., 2016; Madhav et al., 2017).

Another example is that of Martin Luther when the Black Death haunted Europe. Many fled, yet Luther and his pregnant wife, Katharina, remained to care for the sick, for they respected and depended on Matthew 25: 41 to 46 where Jesus Christ said "I was sick and you did not visit me." In the letter written to Christians, Martin Luther expressed much faith in God as he reported that he was not alone with the deacons but Jesus Christ was ever-present. He further announced his hope to triumph over the devil whom he referred to as the murderer and the author of sin whose head needs to be crushed through faith. Scrivener (2020), comments that the survival of Martin Luther and his wife Katharina vindicated Christian lives in the face of intense trial. Similarly, Charles Spurgeon is one of the Christian leaders who emerged courageous during the cholera pandemic which broke out in 1854 and that struck fear into the hearts of Londoners. Additionally, Berding (2020) reports that Spurgeon regarded the plagues of his day as a 'storm that led many to seek refuge in Christ the Rock'. He was then more than ready to usher them to God whether 
dead or alive. It is therefore evident that pandemics have profound spiritual impacts and thus spiritual giants are needed to care and comfort the spiritually wounded people of the world.

However, Scrivener (2020) warns that even though ancient Christian leaders survived, carers can be carriers, even when asymptomatic. He strongly advises that, rather than infecting the ones we are seeking to love, the most loving thing to do is self-isolation. Contrary to his view, Merritt (2020) surmises that loving God by loving one's neighbour should be the energizing principle for Christians. Moreover, he cites Paul's example who wrote encouraging letters to the Philippians when they were facing severe pressure that was dividing the church, just like the COVID-19 pandemic. Correspondingly, Marshall (2020) concurs with Merritt Chang by expressing that the pandemic's impact on religious groups is also felt beyond the spiritual realm. She maintains that the pandemic affects the broader community that benefits and also relies on religious charity. For instance, many religious communities provide essential social services like child care and hunger relief to the most vulnerable people (Lonas, 2020; Bettis, 2020). Additionally, Bentzen (2020) opines that the impulse to move toward the needy, displayed in heroic sacrifice, is entirely Christlike. He emphasises that Christians dare not be less sacrificial in the love that they seek to embody. On the contrary, Scrivener (2020) warns that heroic sacrifices may be very dangerous. His demise is that the heroic moves in our day when we may ourselves be carriers of the infection and needs careful thought. These statements indicate spiritual heaviness and arguments that are embedded in pandemics.

Examples of how some religious leaders reacted when pandemics swept through countries show deep spiritual burdens that affect both church leadership and congregants. Here are some of the pandemics that have oppressed people spiritually. For example, in 2003 the severe acute respiratory syndrome (SARS) pandemic and growing concerns about the threat posed by avian influenza led many countries to devise pandemic plans (U.S. Department of Health and Human Services, 2005; Madvah et al., 2017). Walsh (2017), refers to the bird flu called H7N9 whereby $88 \%$ of people infected got pneumonia, three-quarters ended up in intensive care with severe respiratory problems, and $41 \%$ died. The contagion of infectious diseases today is far more virulent. In 2017 ten infectious diseases were mentioned that affected and blew over the world but none of them shook the world like COVID-19. Again during the 1918 pandemic, populations experienced significantly higher mortality rates, insufficient access to supportive medical care, and higher rates of disease transmission. During the Black Death, an estimated 30 to $50 \%$ of the European population perished. More recently, the HIV/AIDS pandemic has killed more than 35 million persons since 1981 (De Witte, 2014; WHO, 2016; MADHAV et al., 2017). What is even more spiritually depressing is that, during a pandemic, there is a serious lack of routine care for other comorbidities (Pathmanathan et al., 2014; Moon et al., 2015; Parpia et al., 2016; WHO, 2016a). Moreover, Falcone and Detty (2015), posit that at the peak of any pandemic health care workers are unable to report for duty because they themselves are ill. This means, while they are under pressure caring for others, they themselves need attention. Its stands to reason that their plight has a negative spiritual impact and they need upliftment.

\section{Problem statement}

The prevalence of COVID-19 introduced 'doom and gloom' that covered the whole world. All aspects of society were tampered with and the Christian church community was not spared either. The COVID-19 pandemic triggered unprecedented challenges to the normal operation of all churches around the world whereas, research of all times deemed faith and religion to have long been identified as coping mechanisms during life-threatening situations. Church services, Bible studies and prayer meetings are prominent forms of Christian fellowship where people off-load their spiritual burdens. Tabei et al's. (2016) research revealed that religious beliefs and spirituality 
are deemed beneficial to the maintenance of physical and psychological health. Unfortunately, the closure of churches and other public places has prevented pastors from performing their pastoral ministry and church members from enjoying fellowship with one another. It is against the lockdown restrictions and closure of church houses that this study investigated the spiritual impact that the COVID-19 pandemic has had on Christians leaders and church members/congregants. This study also seeks to explore the negative and positive effects of COVID-19 on church leadership and members.

\section{Purpose of the study}

This study was guided by the following objectives:

1. To evaluate the spiritual impact that COVID-19 has had on Christian leaders and church members/congregants.

2. To explore innovative ways that church leaders can employ to perform their pastoral ministry during and beyond the COVID-19 pandemic.

\section{Methodology}

Within the qualitative methodology paradigm, the participants, the church leaders and congregants were purposively selected from rural and urban areas within the Esikhawini church fraternal. Etikan et al. (2016), define the purposive sampling technique as a deliberate choice of a participant due to the qualities the participant possesses. Moreover, they emphasise that the idea behind purposive sampling is to concentrate on people with particular characteristics who will better be able to assist with the relevant research information. The study adopted an antipositivist epistemological viewpoint which posits that research is undertaken in naturalistic settings, rather than in simulated or artificially created experimental conditions (Creswell, 2014; Buthelezi, 2016). This is why the researcher conducted interviews with church leaders and congregants in their usual and natural settings.

An interpretive framework befitted this study as it deals with generalisations and promotes gaining a deep understanding of life through interpreting the meanings that participants assign to their situations. In essence, qualitative research involves participants' perspectives as human beings evolve and change. To protect the participants from secondary trauma and to be ethical, pseudonyms were used. Data were collected through in-depth unstructured interviews. Thematic analysis was adopted for data analysis. Newman (2011) mentioned that thematic analysis emphasis is on the content of the text, i.e. what is said more than how it is said. The study aimed at revealing personal opinions on the impact that COVID-19 imposed on both Christian leaders and their members of the congregation. Since participants were expected to express their personal views, the interpretive paradigm was chosen for this study (Yazan, 2015). Following Creswell's (2014) ideas on interpretivism, the study had to adhere to the interpretive tradition by seeking to interpret and understand behaviours and attitudes within a natural setting.

The study comprised a sample size of four church leaders and eight church members from ten churches. A total number of 12 twelve heterogeneous individual participants were selected. The qualitative research methodology allows for a reflective and critical approach resulting from indepth insight. Further research on issues related to the spiritual impact of the pandemic on the organization of religious life in individual Christian denominations should include statistically representative methods. Individual face-to-face interviews were conducted. Individual in-depth interviews were based on a repetitive research scenario, which alowedaskingrespondents probing 
questions, thanks to which it was possible to refine the research issues. The table below indicated participants' categories and codes that were allocated to them.

Table 1: Categories of participants

\begin{tabular}{|l|l|l|l|}
\hline Categories of participants & Participants & Codes & No. of participants \\
\hline Church leaders & Pastors & Pst A - D & 04 \\
\hline Church members/congregants & $\begin{array}{l}\text { Church } \\
\text { members/congregants }\end{array}$ & $\begin{array}{l}\text { CM1 to CM } \\
6\end{array}$ & 06 \\
\hline Total number of participants & & & 10 \\
\hline
\end{tabular}

\section{Instrumentation}

Data were collected using semi-structured interviews which is a paradigm whose foundation is interpretivism, which gives access to the participants' meaning of their lived experiences (Mertens, 2014). The rich and practical experiences were accessed by allowing participants time to describe, explain and share personal idiosyncrasies. For purposes of this study, data were generated using face-to-face in-depth interviews, WhatsApp communication, available literature and cell phone conversations. The said instruments open chances and possibilities of triangulating findings and interpreting them.

Open-ended questions allowed participants to adequately express themselves and they also allowed opportunities to probe for clarifications. Hence, this study is phenomenological in its research method, and the approach of data collection was within the qualitative design. This design has allowed the researcher to review existing literature and to collect in-depth information as data to present the study in its phenomenological contexts. This is in line with what Chowdhury (2014) sees as the importance of interpretivism because of its ability to enable the researcher to see the world through the eyes of the people that are being studied and to allow them multiple perspectives of reality. The study befitted Chowdhury's (2015) assertion since it sought to explore the participants' personal views, observations and responses in understanding the spiritual impact of COVID-19 in people's lives. The researcher even had the opportunity to adapt questions when necessary (Creswell, 2014).

\section{Data analysis}

Cohen, Manion and Morrison (2013) posit that qualitative data analysis involves organising, accounting for and explaining the data. In this study, the data were interpreted according to participants' definitions of the situation, noting patterns, themes, categories and regularities. This study employed an inductive process by building categories and themes as the researcher made sense of the data that had been interpreted. Qualitative data were, therefore, analysed through thematic analysis. Recorded interviews were subsequently transcribed and analysed according to Creswell's (2014) data analysis steps. To avoid deviating from the targeted objectives, during the data analysis process, objectives were used as a guiding principle in the generation of themes. Data analysis and interpretation involved triangulation to validate the information and draw conclusions.

\section{Research findings}

The COVID-19 pandemic has brought about a lot of negative and also positive spiritual experiences in the church. To the vulnerable, it caused them to become even more desperate in their day-to-day situations. The aim of the study was to evaluate the spiritual impact that COVID- 
19 has had on Christian leaders and church members/congregants and to explore innovative ways that church leaders can employ to perform their pastoral ministry during and beyond the COVID-19 pandemic. The following discussion will focus on presenting the findings of the study.

\title{
Fear of the unknown
}

The study revealed that on hearing the news of the novel Coronavirus attack, people first turned a blind eye but when the lockdown restrictions were announced, they were gripped with fear and felt very anxious and distressed. This is what CM3 said:

\begin{abstract}
When the president announced lockdown restrictions and closure of houses of worship, I felt desperate and betrayed. My heart was gripped with the fear of the unknown. I was so used to discussing my frustrations and triumphs with my pastor. Now he seemed so far and unreachable. I felt lonely and afraid. There was unutterable spiritual heaviness around me...

In concurring with the church member, PST 2 said: Church members were so discouraged, they kept on calling for reassurance that things would be normal. I was disturbed by those who needed support and constant counseling hence I quickly organized church members who are professionals in the health sector to address the church on what COVID-19 is, what to expect, how to behave and to emphasise cooperating with the lockdown restrictions...
\end{abstract}

The mentioned conversation corroborates Marshall's (2020) assertion when he posited that church leaders were hard-hit spiritually by COVID-19. People looked up to them for answers yet they were also rendered powerless by the restrictions imposed by the state authorities.

\section{Church leaders' predicament}

The findings revealed that ministers and pastors who generally served as pillars of strength, and as sources of guidance and shepherds to God's people, suddenly became helpless and powerless as they were barred from encouraging and comforting their members who were lonely in hospital isolation wards. This corroborates Bettis' (2020), Calo, Murray, Francis, Bermudez and Kraschnewski (2020) and Jamir (2020), assertions that church leaders were indeed rendered powerless in the face of the pandemic.

PST 4 had this to say: One of my ministries is to pray for the sick, do home visits for the congregants in need especially the elderly, and do hospital visits. I watched helplessly as my church members died in isolation, in hospitals. It was also very difficult to stop visiting the sick and the elderly in their homes. This had a negative spiritual impact on me and the people I take care of because to me it felt like negligence and to them it felt like rejection.

Apart from the sick, the scourge of gender-based violence gained momentum (Mlambo-Ngcuka, 2020). Again in this instance, pastors could not intervene properly since they could not sit down with a family for mediation purposes. This imposed a lot of spiritual pressure on the abused and thus spiritual heaviness grew even for the pastors who had been rendered helpless. This is in line with Mlambo-Ngcuka's assertion that COVID-19 caused women to be locked down with violent partners while separating the abused women from the people and resources that can best help them. This was supported by statistics that revealed 243 million women and girls have been subjected to sexual or physical violence by an intimate partner globally. These facts attest to the negative spiritual impact that COVID-19 imposed on people. 
PST 1 asserted: not being able to work and drink alcohol was so frustrating that gender-based violence and physical abuse in families increased. Marriages were adversely affected. Even in times of violence, I could not visit couples for mediation and counselling. The abuse has a negative spiritual impact on abused Christian members who could neither go to church for fellowship and solace nor share their plight with the pastor or church elders. Serious matters like physical and sexual abuse in families gained momentum yet I could not help.

Moreover, it brought about a lot of conflict within the church community on matters of whether churches as places of worship should open or not. To some degree, some reactions were seen as disobedience to leadership and authority. Dreyer (2015) expresses that during the pandemic the church experiences crisis due to stress. At this time, the church as an institution experiences difficulty when structures, finance and traditions are under pressure. Marshall (2020) posits that the COVID-19 crisis involves both 'sprints and marathons' and familiar yet unprecedented challenges that will have far-reaching repercussions for global affairs especially, the church community. Additionally, Grimke (2019), adds that the COVID-19 pandemic has interfered with three aspects of religious life, namely: congregation, religious rites and pastoral care, and charitable work. Due to a lack of services for fellowship, many Christians became desperate and sank into depression (Osei, 2020; Scrivener, 2020).

\section{Absence of church services - a spiritual handicap}

Marshall (2020), posits that the COVID-19 disrupted people's lives since the presence of religious groups help people find meaning and maintain hope in the face of threats and disrupted lives. The magnitude of the damage is attested to by Calo et al. (2020), which confirms that $80 \%$ of people around the world adhere to religion. In other words, religion becomes a pillar of strength to those who believe. Typically, religious traditions remind people that their forebears were tested and emerged stronger from past trials. Nicolaides (2020) asserts that the standing of meditation and one's relationship with God becomes paramount in times of stress and excessive anxiety. This knowledge provides some reassurance that they too, will emerge stronger in this crisis. The survival and revival of faith are stirred through fellowship. Referring to the mentioned statements, it can be concluded that the COVID-19 disruption has had an intense negative spiritual impact on the Christian community.

CM 1 desperately asserted: "I have spent all my life in the house of the Lord. It was just unthinkable that I would ever be barred from attending church services, Bible study, prayer meetings and any other form of spiritual upliftment. This depressed me. Although I can do these alone at home, fellowship with others can never be substituted.

PST 3 further clarified by saying: Speaking of the negative spiritual impact, youth was hard hit when church houses were closed. Most of them got so distracted that they withdrew from Christian living. Lack of consistent prayer lives, Bible studies and the whole church activity caused them to be attracted to circular TV programmes. Some got addicted to pornography movies with nothing to prick the conscience. One thing led to another. Some became more sexually active, more girls got pregnant. Giving counseling sessions over the phone was not as real as the face-to-face ones. 


\section{Untimely death due to lack of spiritual support}

Findings reveal that lack of spiritual upliftment contributed to untimely deaths. Correspondingly, Tabei et al. (2016), reveal that spirituality is one of the natural capacities of humans that has positive effects on individuals' health. Studies have also confirmed that religious beliefs and other spiritual approaches on health have a positive spiritual impact on the ill. Additionally, research has shown that praying and participating in religious activities strongly reduce mortality (Gallup \& Jones, 2000; Koenig \& King, 2012; Tabei et al., 2016). For example, Merrit (2020), painfully observes that thousands of people died alone, without so much as the dignity of a familiar face as they drifted into eternal rest.

CM 6 said: As I survivor, it was spiritually depressing to lie in a hospital ward where neither my pastor nor family could visit comfort and pray with me. I believe more people could have survived if they were spiritually fed with faith. I was so scared, it seemed as if the hospital was infested with demons. The health personnel was also unsettled. I sometimes thought that they, like me, also needed spiritual support for strength.

Funerals services were considered to be a disaster with no proper closure for families. Marshall (2020) expressed that the Coronavirus presented barriers to caring for the sick and to performing certain death and burial rites. These are the core religious practices that are especially needed during a pandemic that has already claimed very many lives. It follows then that some people died unhappily. Additionally, Lonas (2020) highlights that people could not gather and find closure, comfort, or a shoulder to cry on. In this instance, church leaders were requested to bury their deceased members under extreme pressure from the Government as well family members. Everything happened abruptly. Due to the limited number of people that had to attend funerals, church members could not pay tribute to their departed colleagues (Bettis, 2020; Merritt, 2020). This means that the death of the loved ones left the survivors with very heavy spirits that may impact negatively in their lives for a long time to come. For instance, in Sri Lanka, authorities made cremation mandatory even when families did not agree with it nor like it. Loneliness characterised bereavements. Chaplains concur that people find comfort in knowing that they are enduring the crisis together. This is where spiritual fellowship is most needed (Marshall, 2020). This was proved by CM 6 when she said:

"Although I survived, my spouse did not. I would have loved to be surrounded by my family and my church members during bereavement. Under the prevailing circumstances, we had to observe social distancing and take precautionary measures against spreading the virus. Given the above, I may say that my husband was buried by strangers since fellow Christians had to give way for family members to adhere to only the 50 people principle. Family members who are so distant to me. I could not view, touch nor speak to him. His sons and daughters could not surround him as he drifted to death. Ehrr ....(wiping tears)... he died lonely (crying), I can say, he was not accorded the dignity he deserved. That impacted negatively on my spirit. I have a lot of unanswered questions".

\section{Exclusion of the church by government in crucial decisions}

Still, on a negative note, the COVID-19 pandemic also posed challenges that led to conflicts among the religious community. The most important was that the government did not include church leadership in important decisions like closing down church houses. A minority of religious leaders rejected prohibitions on gatherings flatly, while the large majority of people supported 
them. Around the world, individual houses of worship like churches, mosques, synagogues and temples simply chose to close in response to the pandemic (Marshall, 2020; Calo et al. 2020; Murff, 2020).

History has proved that governments tend to forget the strength of religious leaders in building communities. For example, during previous outbreaks of HIV/AIDS in the U.S. and around the world, and of Ebola in Central and West Africa, the strengths of religious communities were rarely incorporated into public policy. Hence, it is said that religious communities adjusted willingly or grudgingly to the disruptions caused by COVID-19. Limiting church events led some people to see these measures as an imposition on their freedom of religion, creating significant tensions between the public and the state. Because of the common separation between governments and religious organizations, it can be easy to overlook the significant role that religious leaders and groups have played in responding to pandemics before, and in providing health care overall. Although they felt ostracised, religious leaders and faith-inspired organizations have mobilized to respond to the pandemic's impact on vulnerable communities, with volunteers and financial resources to meet the needs of the sick, the elderly and poor communities (Grimke, 2019; Lonas, 2020; Marshall, 2020).

Church leadership was excluded despite Marshall's (2020) assertion that religious leaders are instrumental in conveying messages during times of crisis. Further, they have deep knowledge of local communities. Moreover, religious leaders can draw on theology and stories to transmit even basic public health suggestions, like how to take care of the self and others in fighting the pandemic. Additionally, Scrivener (2020), Suarez (2020) and Kofferman (2014) avers that religious leaders can model constructive behaviours by applying social distancing, respecting quarantine requirements and generally influencing the community who are their church members to comply. Grimke (2019) posits that religious leaders are often among the most trusted categories of leaders although others have proved to be unethical in their conduct. In this instance, they can play a vital role in tackling fear and misinformation surrounding the COVID-19 pandemic. Regarding the helpfulness of the religious sector, PST 2 had this to say:

While we have responded to God's calling to shepherd the flock - His people, our very church members are under Government custody. ..............., I think the Government officials should have consulted church leaders in COVID-19 matters that concerned churches. The exclusion of pastors by the government, caused them to be uncomfortable.

To prove that the community or church members trust church leaders more than the government, this is what CM 4 had to say:

It was as if people don't believe how dangerous and deadly the coronavirus is, but the moment Esikhawini Fraternal church leadership started driving around the township telling people to comply, people responded positively.

This statement shows that even though a lot of negative impacts were experienced, church leadership found ways and means to participate positively in combating the spread of the COVID19 pandemic. However, amid the difficulties, Sulkowski (2020) highlights that the role of clergy and those responsible for spiritual life is still important. Nicolaides, (2014) argues that the role of religion particularly in the public sphere, involves a very unique and private matter of faith in a God and that clergy have a huge role to play in driving such matters. Having enumerated elements that had a negative spiritual impact, the following findings are positive. 


\section{Unity among fraternal ministers}

Marshall (2020) argues that closing a house of worship to prevent the spread of the coronavirus can put the beneficiaries of these programmes in danger. In Philadelphia, the head of the food distribution programme said that the threat of COVID-19 is not as real as the threat of hunger. In this case, PST 3 had this to say:

In our fraternal, COVID-19 presented us with an opportunity to unite as leadership from different churches and take charge of helping the community. We had zoom meetings where we decided to collaborate and drive around Esikhawini raising awareness through loud-hailing and giving people pamphlets that encouraged people to take precautions. We sounded a clarion call to Esikhawini churches to contribute money to a pool fund. We then bought food parcels and distributed them to needy families regardless of which church they attended. We were immediately transformed into Kingdom citizens instead of exalting our churches one above the other. We were driven by one purpose serving the nation.

\section{Church members took a leadership role}

Apart from church leaders who took responsibility for serving the community, ordinary church members who are professionals were also useful to the church.

CM 2 even said: You know, everything works together for good for those who love the Lord. Lockdown came as an opportunity for me. As a doctor, I got a chance of addressing church members through live streaming to empower them about what COVID-19 is, how can people protect themselves. I was more vigilant, I studied more since I had the opportunity of sharing my knowledge with others. moreover, an opportunity to save lives.

To this effect, PST 1 said "COVID-19 opened more opportunities to those who were not so active in the church. Nurses, doctors and policemen helped with COVID-19 related teachings. These opportunities empowered them and therefore uplifted them spiritually. I can ascertain that they will never be the same.

Moreover, Osei (2020) posits that ordinary church members were immediately promoted into leadership roles. Elders in families were requested to lead scripture readings and prayers in their families. Additionally, Merritt (2020), opines that a call to pray from home transferred greater responsibility to non-ordained members. He further avers that praying from home brought a faithful realisation that all can have access to God through Jesus Christ according to Ephesians $2: 18$, and all have the priestly responsibility of interceding for other people to God according to 1Peter 2:9:

In this instance, CM 5 asserted "I got a chance to lead prayers at home and I felt strengthened spiritually. Initially, I was afraid but I gradually got used to it. We got strengthened by Bible messages that were sent through WhatsApp. .....but, yoooo! although a good thing, the messages could be mind-bottling sometimes. I also want to commend pastors, young and old for adapting to changes quickly. Nevertheless, live streaming may never replace church worship altogether. It robs us of testifying about Christ, the chance for the laying on of hands to the sick and getting counseled the usual way". 


\section{Technology and online service}

Murff (2020) highlights that due to the closure of church houses, the digital church that has been a mystery came into being. The digital age realities showed that technology is a powerful tool at our disposal. In this instance, Suarez (2020), demonstrates by saying that what seemed like a catastrophe (suspending in-person services) turned into an opportunity to extend the reach of the local church. Moreover, Murff (2020) advised that the Christian family should view this as an opportunity that could potentially position the Church for its greatest evangelistic growth in generations. Encouragingly, he maintained that the church needs to be thinking about building an intentional community online as well. Additionally, Marshall (2020) commended religious leaders for coming up with innovative and creative options that have inspired their communities to accept and adapt to the new reality. This new reality was made possible by, young men and women with technological insight. They stepped forward and were willing to assist church leadership with live streaming.

PST 4 asserted: Thanks to our ICT people. When I approached young ladies and gentlemen to assist us, they did all in their power to see that our services were broadcasted. Moreover, they advised that church services could be attended through zoom. Indeed Psalm 127:3 that reads 'behold, children are a heritage from the Lord, .......like arrows in the hands of a warrior, so are the children of one's youth, came into fruition. They were indeed like arrows in the hands of the church.

It should be borne in mind though, that if leaders were not flexible enough, the technologically advanced individuals would never have helped. This confirms Suarez's (2020) assertion that one of the characteristics of a greater leader is his or her ability to adapt to change. Marshall (2020) attests and elaborates that religious leaders did demonstrate creativity and generosity and have worked hard to adapt to the circumstances, finding ways to practice faith and serve their communities even under exacting restrictions. Further, Suarez (2020) advocates that the church has met with the most intentional opportunities for discipleship. He maintains that great Bible studies coupled with Facebook groups or Zoom, Microsoft teams and other forms of social media, can help the church can continue to provide excellent discipleship opportunities for various communities.

PST 3 said: The new journey had begun. We as pastors had to be innovative and see how we engage our church members. We encourage home churches, recorded prayer themes and sent them through WhatsApp messages. We worked with young church members who were technologically advanced to record messages to live stream through Facebook, YouTube, zoom and other platforms. This was an opportunity of a lifetime since those who were not regulars, got a chance you worship. But, for the elderlies, this impacted negatively since they had always been used to seeing a preacher in front of them. A paradigm shifts indeed.

Marshall (2020) argues that religious leaders play a vital stabilising role during such global crises through offering a beacon of hope amid the ravages of the pandemic. Moreover, Sulkowski (2020) adds that it can be concluded that their opinions are a valuable contribution to the discussion about the pandemic itself and its importance to the life of religious communities. Nevertheless, the very providers of hope, the religious leaders were hard hit by this pandemic. They confessed that they entered into an unprecedented new era for the Church (Murff, 2020). Similarly, Calo et al. (2020) confessed the seriousness of the situation when they expressed that there are no courses on pandemics and contagions in Bible schools or seminaries, neither are there easy 
answers or one-size-fits-all solutions to when and how churches should operate during the pandemic.

In addition, Jamir (2020) expressed the opinion that religious leaders are facing this type of crisis for the first time, and what is even more difficult is that communities process data differently and are impacted differently. This suggests that leaders have to adapt to the drastic change faced in society. It is for this reason that Suarez (2020) emphasises that one of the characteristics of a greater leader is his or her ability to adapt to change. Notably, change does not happen easily. It is for this reason that COVID-19 is deemed to have exerted a very negative spiritual impact on church leaders and congregants. The mere fact that some congregants died lonely in hospitals without spiritual comfort from leaders, and the fact that through lockdown stringent regulations, religious leaders could not do routine home visits even for the elderly, shows how severe the situation has been (Lona, 2020; Merrit, 2020; Marshall, 2020).

By contrast, Lonas (2020) argues that the church cannot afford not to build the type of community online that provides comfort to the hurting, peace to the distressed, and hope to the hopeless. In concurring with Lonas (2020), Murff (2020) expresses the idea that since people are scared and confused and filled with anxiety, online services are not enough of a support mechanism. He maintains that this is the chance to share the words of Christ and encourage the people not to fear. The church would have loved to share ideas with the government but the church has been excluded from sharing ideas for some or other reasons.

\section{Conclusion and Recommendations}

Findings reveal that COVID-19 had a negative spiritual impact on Christians in the study area. On the other hand, it opened opportunities for leadership roles for ordinary church members. Moreover, church leadership explored innovative ways of ministering to church members through technology. To sum up, the COVID-19 pandemic reminds us that we are spiritual beings. It also came with the realisation that it is a challenge that requires global cooperation and unity. Moreover, it revealed how much compassion and a greater responsibility to exercise our faith to witness divine intervention is needed. The COVID-19 pandemic has brought the world to a halt and many people are suffering. For example, it has had huge negative health and economic impact that will be di with us for a long time (Lonas, 2020). Church members are going through a lot of challenges occasioned by the pandemic. Care can be in form of visitation (if possible), phone calls, sending of encouraging text messages, leading the church to give monetary or material tokens to needy church members, and other ways that will make the church members feel the positive impacts of the pastors and the churches in their lives and often dire situations.

Based on the study objectives, the study revealed that the COVID-19 pandemic had both negative and positive spiritual impacts on Christian leaders and church members/congregants. The study revealed that on complying with the restrictions, some church leaders were flexible enough to accommodate change. Subsequent to the findings, the following are the recommendations:

- Church leaders should be proactive in accommodating the change. For instance, the internet ministry has been in existence for a long time but it underutilised. This corroborates Murff (2020) who posits that this ministry was viewed with disdain. If this was adhered to early, the paradigm shift would not have been this difficult to make.

- Each pastor should teach his/her congregants how to respond to pandemics as Madhav et al (2017) projects that due to "zoonotic" virus transmissions, the virus is bound to come and go. 
Pharos Journal of Theology ISSN 2414-3324 online Volume 102 - Special Ed 2 (2021)

Copyright: @2021 Open Access/Author/s - Online @ http//: www.pharosjot.com

- Churches should learn to adapt to multi-staff ministry where committed professional Christians, although not ordained, should serve the church through sharing knowledge that may better prepare the church for pandemics. These are doctors, nurses, teachers, ICT people, etc.

- While traditional ways of pastoring are acceptable, pastors should embrace the use of the Internet and other technological tools in their pastoral ministry.

- Since the COVID-19 period proved that homes can be turned into churches, more emphasis should be placed on cell groups where people can worship more intimately.

\section{References}

Archimandrite, Themistocles (Fr. Themi) Adamopoulos. (2014). Ebola crisis in Sierra Leone and the orthodox mission. Orthodox Christianity. Available online at https://orthochristian.com/75263.html

Bentzen, J. (2020). In a crisis, we pray: Religiosity and the COVID-19 pandemic [Unpublished manuscript]. https://www. dropbox.com/s/jc8vcx8qqdb84gn/Bentzenreligiositycovid.pdf?dl=0

Berding, K. (2020, March 16). How Did Early Christians Respond to Plagues? Historical Reflections as the Coronavirus Spreads. The good Book Blog. https://www.biola.edu/blogs/goodbook-blog/2020/how-did-early-christians-respond-to-plagues

Buthelezi, Z.G. (2016). "At the Policy-practice Interface: Exploring Technical Vocational Education and Training (TVET) Lecturers' Post-Apartheid Educational Reform Experiences." Unpublished Ph.D. thesis, University of KwaZulu-Natal, Pietermaritzburg.

Bettis, K. (2020, May 29). Pastoral submission amid a pandemic: Who should Christians heed when following Romans 13 and Hebrews 13 seems to conflict? Christian Today. https://www.christianitytoday.com/ct/2020/may-web-only/covid-when-pastors-parishionersdisagree-churches-reopen.html

Chowdhury, M. F. (2015). Coding, sorting and sifting of qualitative data analysis: Debates and discussion. Quality \& Quantity, 49(3), 1135-1143.

Rosa, C. (2017). Contagion Infectious Diseases Today. (2017). The 10 Biggest Infectious Disease Outbreaks of 2017. Infectious Disease Today. US

Cohen, L., Manion L. \& Morrison, K. (2013). Research methods in education. London: Routledge.

Creswell, J. W. (2014). Research Design: Qualitative, Quantitative and Mixed Methods Approaches (4th ed.). London: Sage Publications Ltd.

De Witte, S. N. (2014). "Mortality Risk and Survival in the Aftermath of the Medieval Black Death." PLoS One, 9(5), e96513.

Dreyer, W. A. (2015). The real crisis of the church, HTS Teologiese Studies/ Theological Studies 71(3), Art. \#2822, 5 pages. http:// dx.doi.org/10.4102/hts. v71i3.2822

Etikan, I., Musa, S. A. \& Alkassim, R. S. (2016). Comparison of convenience sampling and purposive sampling, American journal of theoretical and applied statistics, 5(1), 1-4. 
Evans, D. K., Goldstein, M. \& Popova, A. (2015). Health-Care Worker Mortality and the Legacy of the Ebola Epidemic, The Lancet Global Health, 3(8), e439-e440.

Falcone, R. E. \& Detty, A. (2015). "The Next Pandemic: Hospital Response." Emergency Medical Reports, 36(26), 1-16.

Gallup, G., \& Jones, T. K. (2000). The next American spirituality: Finding God in the twenty-first century. Colorado Springs, CO: David C Cook.

Grimke, F. J. (2019). Some Reflections on the 1918 influenza pandemic: Growing out of the Recent Epidemic of Influenza that Afflicted Our City. An online journal of literature and the arts, 18(1).

Koenig, H., King, D. \& Carson, V.B. (2012). Handbook of religion and health. OUP: USA.

Lonas, J. (2020, March 16). Love in an Economic Crisis., The Gospel Coalition. Tennessee, USA.

Madhav, N., Oppenheim, B., Gallivan, M., Mulembakani, P., Rubin, E. \& Wolfe, N. (2017).

"Pandemics: Risks, Impacts, and Mitigation". In: Disease Control Priorities (third edition): Volume

9, Disease Control Priorities, edited by D. T. Jamison, H. Gelband, S. Horton, P. Jha, R. Laxminarayan, C. N. Mock, R. Nugent. Washington, DC: World Bank.

Marshall, Katherine and World Politics Review, "What Religion Can Offer in the Response to COVID-19" (2020). Pandemic Response and Religion in the USA: Doctrine. 53.

https://scholarworks.wmich.edu/religion-pandemic-doctrine/53

Merritt, J. (2020). 'Some of the Most Visible Christians in America Are Failing the Coronavirus Test. In place of love, they're offering stark self-righteous judgment' Atlantic, April 24, 2020,

Mlambo-Ngcuka, P. (2020, April 6). Violence against women and girls: the shadow pandemic. Statement by Phumzile Mlambo-Ngcuka, Executive Director of UN Women. UN Women, Geneva, Switzerland.

Moon, S., Sridhar, D., Pate, M. A., Jha, J. K. \& Clinton, C. (2015). "Will Ebola Change the Game? Ten Essential Reforms before the Next Pandemic". The Report of the Harvard-LSHTM Independent Panel on the Global Response to Ebola. The Lancet, 386 (10009), 2204-21.

Murff, J., (2020, April 6). Streaming Your Sunday Service Isn't Enough. Institute for Digital Ecclesiology, US.

Nicolaides, A. (2020). Contemplating Christian ethics and spirituality for sound leadership in organisations, Pharos Journal of Theology, 101: a.37.

Nicolaides, A. (2014). Jürgen Habermas on the value of religion, Philosophia (Philippines) 15 (2), 236-251.

Parpia, A. S., Ndeffo-Mbah, M. L., Wenzel, N. S. \& Galvani, A. P. (2016). "Effects of Response to 2014-2015 Ebola Outbreak on Deaths from Malaria, HIV/AIDS, and Tuberculosis, West Africa, Emerging Infectious Diseases, 22(3), 433-41. 
Pathmanathan, I., O'Connor, K. A., Adams, M. L., Rao, C. Y. \& Kilmarx, P. (2014). Rapid Assessment of Ebola Infection Prevention and Control Needs-Six Districts, Sierra Leone, October 2015, Morbidity and Mortality Weekly Report (MMWR, 63 (49), 1172-74.

Calo WA, Murray A, Francis E, Bermudez M, \& Kraschnewski J. (2020). Reaching the Hispanic Community About COVID-19 Through Existing Chronic Disease Prevention Programs. Prev Chronic Dis, 17. 2020; 17:200165. DOI: http://dx.doi.org/10.5888/pcd17.200165

Porta M., (2014). A Dictionary of Epidemiology. 6th ed. Oxford: Oxford University Press.

Rubinson, L., Mutter, R., Viboud, C., Hupert, N. \& Uyeki, T. (2013). Impact of the Fall 2009 Influenza A(H1N1) pdm09 Pandemic on US Hospitals. Medical Care, 51(3), 259-65.

Scrivener, G. (2020, March 16). Responding to Pandemics: 4 Lessons from Church History. Anglican Mainstream. Retrieved from: https://anglicanmainstream.org/responding-to-pandemics4-lessons-from-church-history/

Stark, R. (1996). The rise of Christianity. San Francisco: Princeton University Press \& Harper.

Stark, R. (2011). The triumph of Christianity: How the Jesus Movement Became the World's Largest Religion (New York: Harper One, 20(11), 114-119.

Suarez, T. (2020, May 209). When Pastors and Pews Disagree on Churches Reopening. Christianity Today, US.

Sulkowski, Ł., (2020). Covid-19 Pandemic; Recession, Virtual Revolution Leading to Deglobalization? Journal of Intercultural Management, 12, 1-11.

Tabei, S., Zarei, N. \& Joulaei, H. (2016). The Impact of Spirituality on Health, Shiraz E Medical Journal, 17(6), DOI: 10.17795/semj39053

Walsh B. (2017). The world is not ready for the next pandemic. Time Magazine; 2017. May 15th 2017. http://time.com/magazine/us/4766607/may-15th-2017-vol-

Jamir, T. (2020). "Empowering Laity to Engage in Pastoral Care Ministry: A Proposal for Capacity Building and Supervision for Larger Congregation with Special Reference to Kohima Ao Baptist Church, Nagaland, India." (2020). Master of Theology Theses. 17. https://digitalcommons.luthersem.edu/mth_theses/17

Witvliet, J.D., Snyder, N., Cornou, M. \& Jang C.G (2020). Pandemics and Public Worship Throughout History

WHO (World Health Organization). (2010). "What Is a Pandemic?" WHO, February 24. Available online at http://www.who.int/csr/disease/swineflu/frequently_asked_questions/pandemic/en/

WHO (World Health Organization). (2016a). Ebola Situation Report. Weekly data report, April 15.

Yazan, B. (2015). Three approaches to case study methods in education: Yin, Merriam, and Stake. Qualitative Report, 20(1), 134-152. 
Note: This study forms part of the research project: Investigating local indigenous community perspectives in response to the COVID-19 pandemic: An invisible enemy in the midst of our local households, supported by the National Institute for Humanities and Social Sciences (NIHSS), under Health and indigenous knowledge systems (IKS) Research Cluster. 